\title{
〔論説〕
}

\section{子育て期の家族に魅力ある市街地環境整備に 関する基礎的研究}

\section{A study on a method of urban planning for making comfortable living environments for child realing family}

Kasumi SUSAKI : Mitsubishi Research Institute, Inc

寿崎かすみ*

Yoshinobu KUMATA : Chiba University of Commerce

熊田 禎宣**

A drastic decline of fertility has alarmed Japanese society and it also means reducing housing market. In this paper it is assumed that preparing comfortable living environment for child realing family becomes one solution to solve declining fertility. Thus making a comfortable living environment for child realing family is a big task not to reduce a housing market. And to do that, it is necessary to introduce marketing concept to urban planning process. The concept is that customer's needs are different depending on sex, ages, living conditions and etc. and it is necessary to check their own needs.

In this paper, it is examined that own needs of child realing families are not checked through urban planning process. And then a new method of urban planning is proposed which encourages to check own needs of child realing families and also confirms acceptability of the proposed method.

Keywords : urban planning, child realing family, housing market, marketing concept

都市づくり, 子育て期の家族, 住宅市場, マーケティング

\section{1. 研究の目的}

1995年の合計特殊出生率1.42が続くならば, 53 年後には人口が半減し, 労働力人口の減少のみな らず，消費市場の縮小につながり，中長期的に日 本経済を衰退に導くという指摘がある ${ }^{1)}$ 。消費市 場の中でも不動産市場は大きな影響を受けること が予測される。住宅需要と人口動態, 世帯動向の 関係を分析し, 晚婚・非婚, 少子化, 長男 - 長女
の結婚が増えたため親の家を利用できる機会が増 えたこと等が住宅需要に影響を与えていることも 指摘されている2)。

逆に，東京都において家賃，住居の広さの他，周 辺環境等の状況が夫婦の出生力に影響しているこ とも指摘されており ${ }^{3)}$, 不動産市場のあり様が少 子化の原因の一つである可能性も示唆されている。

本論文では, 少子化は不動産市場の衰退に直接 影響する問題であること, 逆に住宅供給, 市街地

*寿崎かすみ (すさき かすみ)・正会員 三菱総合研究所 **熊田禎宣 (くまた よしのぶ $)$ 正会員 千葉商科大学 
環境整備は結婚，出産という個人のライフスタイ ルに影響し，少子化の一つの原因となる可能性が あることから, 不動産市場の需要喚起のためにも 少子化対策への積極的な取り組みが必要であると いう立場にたち，子育て期の家族には住居，住居 を取り巻く市街地環境に対する固有のニーズがあ り，このニーズに応えるには不動産市場と都市計 画の協働が必要であることをのべる。さらに都市 計画法で「あるべき市街地像を定めるべき計画」 と位置づけられた都市計画マスタープランの策定 過程で，子育て期の家族の固有のニーズの確認が 行われていないことをはじめとし，都市計画によ る対応が不十分であることを調査により実証する。 最後に子育て期の人々のニーズを収集する上での 問題を調查結果に基づいてまとめ，子育て期の家 族のための居住環境整備を行うための枠組を提案 する。

\section{2. 子育て期の家族固有の居住環境への ニーズ}

\section{(1)保育園を利用する父母の居住環境へのニーズ}

女性の就労と出産・子育ての両立支援は, 少子 化対策の大きな柱である。そこで, 就労と子育て の両立をしている子育て期の家族として保育園を 利用する父母の居住環境へのニーズを調査するた め，東京都内に住み乳幼览を保育園に預けて就労 している母 32 人, 父 1 人 (既成市街地内の住宅地 母 15 人, 父 1 人, 計 16 人, 多摩ニュータウン母 17人）を対象とするインタビュー調査を 1996 年 10 月，11月に行った。インタビュー対象は「保育園 に子どもを預けている」ということのみを条件と して選定したため，対象者の年齢，職種をはじめ 子どもの人数，子どもの年齢等にはバラツキがあ る。また, 父母の居住環境への潜在的な要求を浮 き彫りにするため，杉並区を中心とする既成市街 地内の住宅地と, 計画に基づいてつくられた多摩 ニュータウンの 2 地域で調査を行い, 結果を比較
した。

調査結果より，保育園などの保育サービスが整 っていることはもとょり, 幼児の徒歩圈で日常生 活の一通りの用事が足りるように商店街，郵便局 などが整っていることなど公共・公益施設の存在 だけでなく，近接性が重要な要因であることを確 認した。遊具のある児童公園，ボール遊びなどで きる公園等子どもの年齢に応じ必要となる遊び場, 図書館，児童館など地域の公共施設があることも 重要な要因とされている。また，時間外診療を行 い，急患への対応が頼める小坚科医を始めとする 医療施設へのニーズもみられた。この他，幼児を 連れての移動を確保するため，公共交通網の整備 とアクセスの良さが大きな要因となっている。さ らに，子育て中の父母がその両親に子育て支援を 求めるケース，両親の介護を担うケースなどもあ り, 祖父母との同居, 近居が可能な住宅も必要と されている。ベビーシッターを頼む相手を確保す るためには, 独身の若者や子どもが手を離れた世 代が住み合える住宅地が求められている。集合住 宅のエレベーター，公園等で，子どもが変質者の 被害に合うこと, 交通事故等に対する不安感もみ られ，安全の確保に対する意識が強く見られた。

今回のインタビュー調査の中では, 自治体の保 育園の整備率, 保育園との距離, 祖父母との近居 が転居要因ともなっていた。

今回の調査はサンプル数が少なく，地域的にも 限られており，この結果より得られたニーズが普 遍的なものとは言い切れないが，子育て期の家族 には各地域の状況に応じた固有の居住環境へのニ ーズがあることが予想される。

\section{(2)居住環境へのニーズ調査にみる子育て期の家族 のニーズ}

居住環境へのニーズに関する調査として住宅・ 都市整備公団による「家族像の変化と今後の住宅 需要に関する研究」4)，「ニュータウンにおける女 性就業ニーズに関する調査研究」5）がある。

家族像の変化に関連した研究の中では, 親世代 
表 1 本論文のために実施した調査

\begin{tabular}{|c|c|c|}
\hline 対象と方法 & 実施時期 & 実施目的 \\
\hline $\begin{array}{l}\text { 保育園児の父母 } \\
\text { の イ ン 夕 } \\
\text { ビュー }\end{array}$ & 1996年 $10 ， 11$ 月 & $\begin{array}{l}\text { 居住環境への固 } \\
\text { 有のニーズの有 } \\
\text { 無の確認 }\end{array}$ \\
\hline $\begin{array}{l}\text { 全国の区市の都 } \\
\text { 市計画マスター } \\
\text { プラン策定担当 } \\
\text { ヘのアンケート }\end{array}$ & 1998年 9 月 & $\begin{array}{l}\text { 計画策定過程で } \\
\text { 固有のニーズを } \\
\text { 把握しているか } \\
\text { どうかの確認 }\end{array}$ \\
\hline $\begin{array}{l}\text { 全国の区市の総 } \\
\text { 合計画策定担当 } \\
\text { へのアンケート }\end{array}$ & 1999年 9 月 & $\begin{array}{l}\text { 都市整備の総合 } \\
\text { 計画中での扱い }\end{array}$ \\
\hline $\begin{array}{l}\text { 乳幼北の子育て } \\
\text { 中の母親へのア } \\
\text { ンケート調查 }\end{array}$ & 1999年11月 & $\begin{array}{l}\text { まちづくりに参 } \\
\text { 加する上で何が } \\
\text { 障害となるかの } \\
\text { 確認 }\end{array}$ \\
\hline $\begin{array}{l}\text { 全国の区市の児 } \\
\text { 童育成計画策定 } \\
\text { 担当へのアン } \\
\text { ケート調査 }\end{array}$ & 1999年11月 & $\begin{array}{l}\text { 子育ての生活環 } \\
\text { 境マスタープラ } \\
\text { ン策定の意義の } \\
\text { 確認 }\end{array}$ \\
\hline $\begin{array}{l}\text { 全国の区市の都 } \\
\text { 市計画マスター } \\
\text { プラン策定担当 } \\
\text { へのアンケート } \\
\text { 調査 }\end{array}$ & 1999年11月 & $\begin{array}{l}\text { 都市計画マス } \\
\text { タープランに関 } \\
\text { わる制度の見直 } \\
\text { しの妥当性確認 }\end{array}$ \\
\hline
\end{tabular}

と独立した子ども世代の同居，別居，別居の場合 のかかわりかた等についての調査が行われている が，共働きの子ども世代には子育てに関して保育 サービスの利用, 近隣との協力関係の他, 親世代 の協力を期待しており，それが可能な距離での別 居を希望していることが明らかになっている。

女性の就業ニーズに関する調査研究の結果のう ち，育児支援としての「保育園等保育サービス」へ のニーズ, 保育サービスの提供場所について就労 している女性としていない女性で異なる結果がで ている(図 1)。調査結果では第 3 位であるが，子 育て支援機能付き集合住宅は既に商品化されてい る6)。子育て期の人々には, 当事者でなければわ からない特有のニーズがあることがわかる。

\section{(3)子育て期の家族のニーズへの対応}

共働きで子育てをする核家族世帯のニーズにつ

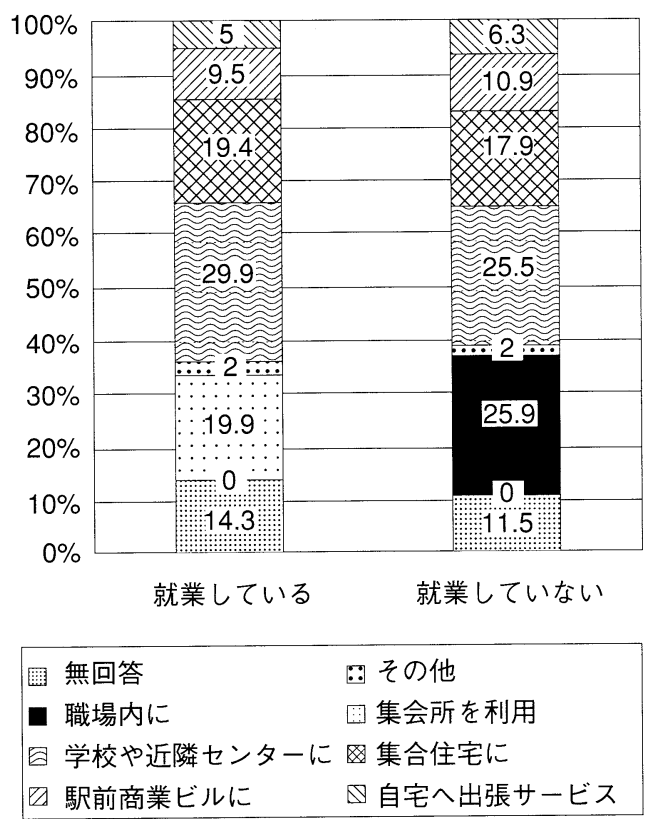

図 1 育児支援希望場所 ${ }^{6)}$ より作成

いては，専用集合住宅の提案 ${ }^{7,8)}$ が1980年代半ば からなされている。住宅都市整備公団でも女性の 社会進出に伴う居住環境へのニーズに関する調査 研究 ${ }^{9.10)}$ が1990年代半ばにあり，商品開発として モデルプランを提案している。

集合住宅の事例分析から，集合住宅に付加する 子育て支援機能の内容が，従来行われてきた認可 保育園の併設から，私設保育所や母親の在宅を前 提とした子育て支援，子育てサークルの活動支援 等まで多様化していることも指摘されており, 子 育て支援機能の付加は，市場競合の中で他と差別 化するための付加価值であると同時に，日中の生 活の軸となる母子の交流が居住者間のコミュニテ イ形成を強化し, 子育て支援がマンションの運営 の重要な要素となるとしている11)。

子育て支援がファミリー世带の呼び戻しに有効 なことは，東京圈についての分析で，保育所の整 備度と夫婦あたりの子ども数, 持ち家率と幼児を 持つ雇用率の間に正の相関があることが明かにな っており, 結婚後も住める住宅の供給, 共働き世 
帯の子育てを支援する保育施策の充実は人口構成 の適正化に働くと指摘している12)。

このように，保育園をはじめとする子育て期の ニーズに応えた居住環境整備には，市場競合の中 での商品価值を高める意味と, 社会的意義の両面 がある。しかし子育て期の家族のニーズでは近接 性，アクセスの良さと関係してサービスの提供さ れる場所が重要な意味を持つため, 居住環境整備 には市街地の面的整備が必要であり, 不動産市場 だけで対応しきれるものではない。都市計画をは じめとする自治体の施策との協働が必要である。 子育て期の家族のニーズが都市整備まで及ぶ様子 をあらわしたのが図 2 である。

\section{3. 自治体の市街地整備における子育て期 の家族のニーズの扱い}

\section{(1)人口減少への自治体の対応}

東京 23 区には定住人口確保策として新婚家庭, ファミリー世帯向けの家賃補助, 住宅ローンの利 子補填などが施策として行われているケースがあ る。子育て支援としてもゼロ歳児保育, 延長保育 の充実などによる保育園の充実をはじめ，私立幼 稚園に子どもを通わせる親のための保護者負担軽 減補助金などの施策が実施されている ${ }^{13,14) 。 ~}$

そこで, 自治体の市街地整備ではこの「子育て 期の家族」への対応がどのようになされているか を把握するため, 都市計画法で「あるべき市街地

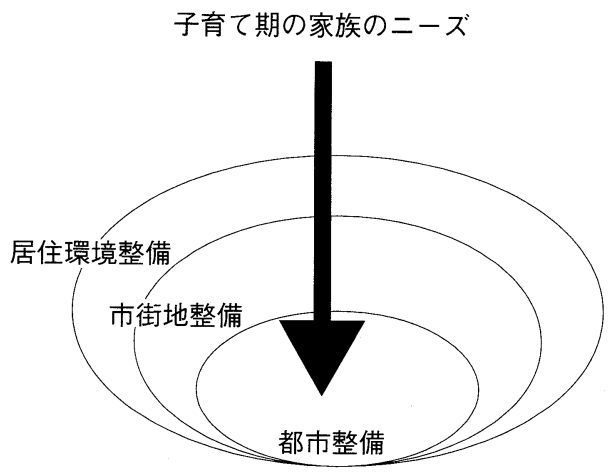

図 2 子育て期の家族ニーズ
像を定める計画」と定められた都市計画マスター プラン（以下「都市マス」）策定過程での市街地整 備への「子育て期の家族」のニーズの扱い，地方 自治法に策定が定められた「基本構想」「基本構 想」に基づく「基本計画」等の総合計画（以下「総 合計画」) 中に示された保育施策等が市街地整備の 中でどのように扱われているかについての調査を 行なった。

\section{(2)都市計画マスタープランの「子育て期の家族」 への対応}

市街地整備の中で「子育て期の家族」のニーズ に対応するには，そのニーズを把握することから はじめる必要がある。子育て期の家族の固有ニー ズを把握する作業を, 都市マスの策定にあたりど の程度実施しているかを確認する郵送アンケート 調査を，1998年 9 月，東京23区および全国の市(合 計 693 自治体）に対して実施した（回答率 $77.2 \%) 。$ 回答のあった自治体のうち都市マス策定済み自治 体は $52.8 \%$ ，策定中 $28.4 \%$ である。

この策定済みおよび策定中自治体のうち，策定 過程で父母対象の調査を行ったと回答しているケ ースは $3.4 \% に$ 過ぎない。さらにその内容は「20年 後を背負う市民として 30 代，40代の市民に総花的 なアンケートを行ったところ父母としての意見も でた」等で，「子育て期」という属性を意識したも のとは限らない。多くの自治体で町内会, 商工会 議所，農業協同組合，漁業協同組合等を対象とす るヒアリングが行われているが, 町内会経由の意 見聴取は, 居住環境整備に関する子育て期の家族 の声を吸い上げる手段としては問題があることも 指摘されており ${ }^{15)}$ ，子育て期の家族の意見を代弁 しうる団体は含まれていない。

以上の結果より，都市マス策定に扔いて子育て 期の家族の固有のニーズの確認をした上での反映 は行われていないという結論を得た。

\section{(3)総合計画に示した施策の市街地整備への反映}

総合計画に記述した福祉施策等と関連して, 実 際の施設配置，施設へのアクセスを確保するため 
の交通計画等の都市整備上の課題が都市計画マス タープランの中でも扱われているどうかを確認す るため，全国の市および東京23区（合計693）を対 象とする郵送アンケート調査を1999年 9 月実施し た（回答率 $75.5 \%)$

回答のあった自治体の都市マスの策定状況は, 策定済み $49.8 \%$ ，策定中 $33.2 \%$ ，未策定 $17.0 \%$ ，そ の他・無回答 $1.9 \%$ である。都市マス策定済み，策 定中の自治体が，福祉施策等と関連した都市整備 上の課題を，総合計画の中で記述していかどうか を図 3 に示す。福祉施策等にかかわる施設整備を 都市マスに記述している自治体は，都市マス策定 済み自治体(策定中含む)の 4 割に満たない(図 3 )。 (4)自治体の子育て期の家族の居住環境へのニーズ

\section{の扱い}

都市マスの策定においては，子育て期の家族の 固有のニーズの確認をした上での反映が行われて いないことが明らかになった。また, 教育, 福祉 等に係わる施設整備などを総合計画でのみ扱って いる自治体が都市マス策定済み(策定中含む) 自治 体の半数を占めており, 都市マスの「あるべき市 街地像」検討の際に考慮されていないことも明ら かになった。

\section{4. 子育て期の家族に魅力ある市街地を整 備するための課題}

\section{(1)子育て期の家族のニーズ把握実現上の問題}

「子育て期の家族のニーズ」という視点から当事

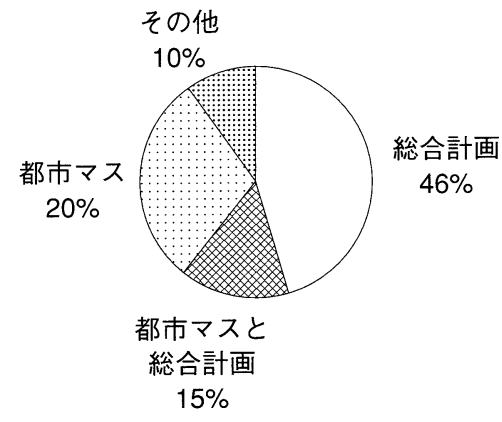

図 3 福祉施設整備を記述した計画
者の意見を直接把握する上で，当事者がまちづく りに参加することは重要であると考える。そこで 当事者が参加する上での問題を把握するためのア ンケート調査を，1999年11月に実施した。全国に ある任意の子育てグループに調査票を郵送し協力 を求めたほか，静岡県沼津市，東京都武蔵野市の 協力を得て，児童館等で調查票を配布した。調査 票は合計 1115 枚配布し，50.7\%の回答を得た。調 査の結果，居住環境に対し問題を感じている人は 8 割にのぼるが，まちづくりに参加する上では， 「子どもがいて思うように動けない $(32.9 \%)$ ，「時 間がない $(17.3 \%) 」, 「$ 仲間がいない・みつからな

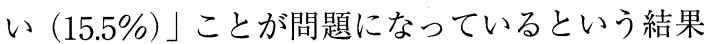
がでた (複数回答)。

さらに実際に活動を行う上では「仲間のスケジ

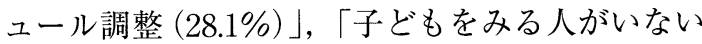
$(27.0 \%) 」$,「相談する専門家がみつけられない $(24.0 \%) 」 の 3$ 項目を指摘する解答が多く，これ

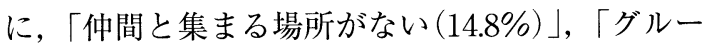
プ間のノウハウ交換が行えない」が続くという結 果がでた。

子育て当事者が居住環境へのニーズについて発 言し，また問題解決に取り組むことを支援するこ とが必要である。また，意見収集を行う上で民間 企業の有するマーケティングのノウハウの活用は 有効であると考える。

\section{(2)自治体の計画システムの変更}

子育て期の人々の居住環境へのニーズを都市整 備，市街地整備，これを包含するものとしての居 住環境整備に反映するためには，都市計画システ ムによるコントロールのもとに不動産市場, 住民 自身のまちづくり活動，NPO法人等の活動を巻き 込み, 結果として居住環境の整備が達成される仕 組みが必要であり，このためには住民，NPO法人， 不動産市場が計画づくり，計画の実現，評価にい たる一連の作業の中で発言し, 意志決定に加わり, 実現のために行動することができる自治体の計画 策定システムが必要であると考える。 
このような計画策定システムとして，子育て期 の人々の意見を集め, 子育て期の人々自身も加わ って対応策を検討した「子育ての生活環境マス夕 ープラン」を策定した上で，他の行政課題等との 調整を行うという方式を提案する。この方式の妥 当性については東京 23 区および全国の市（合計 693）の，厚生省主導の少子化対策である「児童育 成計画」の策定担当者宛の郵送アンケート調査 （1999年11月実施，回答率60.2\%）により確認した。 回答のあった自治体の児童育成計画策定率（策定 中を含む）は $55.0 \%$ あ゙あ（図 4)。

また，市民版都市計画マスタープランに関する 研究16)で，市民の意見を計画としてまとめること により学習が行われる効果があることがあげられ ている。計画の作成団体により視点が異なるため 自治体の行政課題全体からみると抜け落ちる課題 があるという問題はあるが, 独自の視点を持った 複数の計画がつくられ，互いに議論できればよい ということも述べられている。

都市計画マスタープラン策定過程で, 環境等の テーマを持って活動するグループの意見を反映す るしくみが必要であるという指摘もある ${ }^{17)}$

都市計画システムについては，1999年11月，東 京23区および全国の市（合計693）の都市マス策定

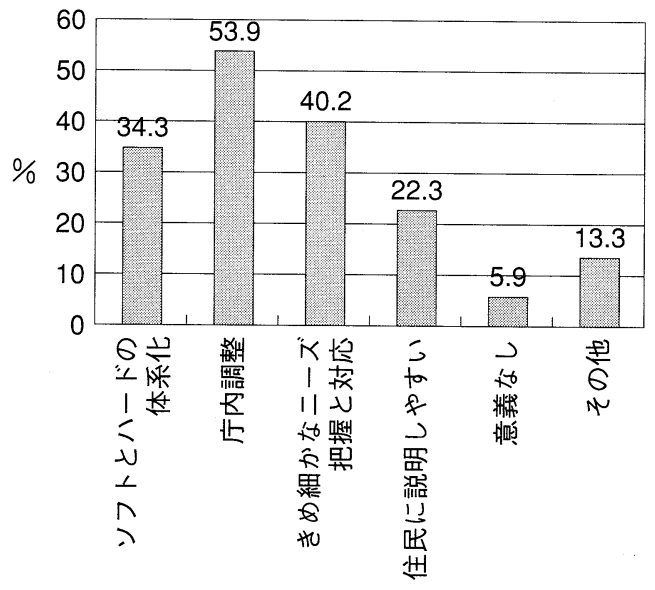

図 4 子育ての生活環境マスタープランの意義
担当者に郵送アンケート調査を行い（回答率 73.9 \%)，都市マスと整備・開発・保全の方針，総合計 画との関倸等の見直すことの妥当性について質問 し，「妥当」とする回答が $51 \%$ という結果を得た (図 5 )。

都市計画システムの変更については，ゴミやリ サイクルなどの環境問題，生活圈での施設配置， サービス水準といった主題も多くなっており，よ り幅の広い都市計画・まちづくりへの対応が必要 になっていることが指摘されている18)。地震発生 時等，防災もまちづくりの重要な課題であるが19)， 防災上は「弱者」である幼い子ども，幼い子ども を抱えた住民に特有の行動を把握することも必要 である。子どもの安全確保という意味では，交通 事故，変質者から子どもをまもる20,21)ことも重要 である。鈴木庸夫 ${ }^{22}$ は交涉行為としての要綱行政 の問題を指摘しているが，このような問題を解決 するためにも計画策定システムの変更が必要であ る。都市整備上の問題である「地価の暴騰」を回 避し, 都市整備の財源を確保するには詳細なゾー ニング23), 開発利益の環元 ${ }^{24)}$ が必要であることも 指摘されている。

不動産市場の制度整備をはじめ，不動産の質と 価格に関する情報等の公表, 公開を含めた不動産 市場の再編が必要である。

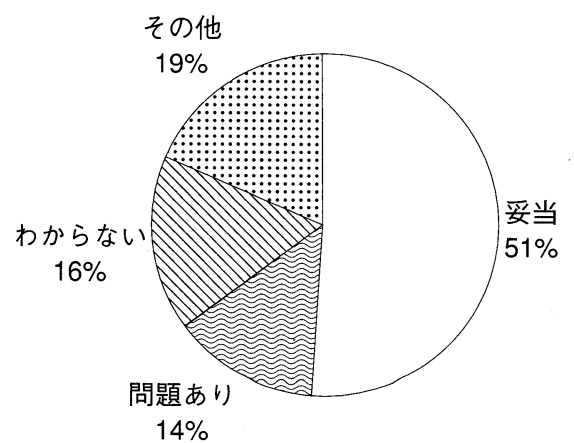

図 5 都市マスに関わる制度の見直しの妥当性 


\section{5. 結論}

不動産需要を喚起するためにも，少子化対策と しての住宅供給，市街地環境整備に積極的に取り 組むことが必要である。子育て期の家族には地域 に応じた子育て期の固有のニーズがあり，それは 居住環境全般に及ぶ。そのニーズについて発言す る場，活動の場を求めている。しかし調査の結果， 自治体の市街地環境整備における子育て期の家族 に固有のニーズを確認した上での反映は，自治体 の延長保育等，保育園のサービス面での反映と比 較しても不十分であることがわかった。子育て期 の家族のニーズにあった市街地環境整備を実現す るためには，自治体の都市計画のコントロールの もとで，不動産市場，NPO法人，住民のまちづく り活動の協働による市街地環境整備を実現できる 新しい計画策定システムが必要である。

自治体の計画策定システム, 都市計画システム の変更, 不動産市場の制度整備, 市場の再編の具 体的内容は今後の課題である。

\section{【参考文献】}

1 ）大淵寛「少子化社会のゆくえ」都市問題 第 88 巻 第 12 号 1997 年

2 ) 阿部成治「家族のライフサイクルと住宅」都市問 題 第 89 巻 第 11 号 1998 年

3 ) 浅見泰司他「少子化現象と居住コスト」人口問題 研究 第 53 巻 第 4 号 1997 年

4 ) 牛山美緒「家族像の変化と今後の住宅需要に関す る研究 (その 2)」調查研究期報 No.110 住 宅・都市整備公団 1996 年

5 ）船塚清隆「ニュータウンにおける女性就業ニー ズに関する調査研究」 調查研究期報 No.116 住宅・都市整備公団 1998 年

6)「ユーザーニーズをとらえた企画型マンション」 月刊不動産流通 No.184, 1997 年 9 月

7 ) 田中智子 - 湯川利和 - 瀬渡章子「看護婦家庭の中 要求」家政学研究 第 32 巻第 1 号 1985 年 9 月

8 ) 田中智子「保育所利用世帯の住要求」家政学研究 第 33 巻第 1 号 1986 年 9 月
9 ) 藤間幹朗「女性の社会進出に伴う居住環境の整備 に関する研究」（その 1) 調査研究期報 No.103 1994 年

10）藤間幹朗「女性の社会進出に伴う居住環境の整備 に関する研究」(その 2) 調查研究期報 No.107 1995 年

11）山本理「集合住宅における子育て支援」都市問題 第 89 巻 第 11 号 1998 年

12）広嶋清志「出生率低下と都市問題」都市問題 第 82 巻 第 7 号 1991 年

13）「特別調查・都市の少子高齢化対策」都市データパ ック 1999 年度版 東洋経済別冊 103

14）「この町が一番すみやすい」カピタン 第 2 巻 第 2 号（株）文芸春秋 1998 年

15）矢郷恵子「住宅まわりを豊かにすることは子育て を豊かにする」都市計画 2141998 年

16）坂口陽子・村田亜紀子・伊藤史子・渡辺俊一「市 民版 マスタープラン」による都市計画マスター プランへの意見反映」第33回 日本都市計画学会 学術研究論文集 1998 年

17）高見沢実「市町村都市計画マスタープランの成果 と課題」都市計画 2191999 年

18）高見沢邦夫「東京都特別区のまちづくりのこれ迄 と今後」(社) 日本都市計画学会地方分権研究小委 員会編「都市計画の地方分榷」学芸出版社 1999 年

19）米岡久徳・梶秀樹「避難経路選択モデルに基づく 街路網評価」第26回日本都市計画学会学術研究論 文集 1991 年

20）斎藤裕美「集合住宅地における犯罪不安感に影響 を及ぼす要因の研究」第26回日本都市計画学会学 術研究論文集 1991 年

21）瀬渡章子「名古屋市の高層・又穂団地における防 犯性能の検討」家政学研究 第 32 巻 第 1 号 1985 年

22）鈴木庸夫「都市環境整備と行政手続き」都市問題 第 85 巻 第 10 号 1994 年

23）野村総合研究所編「地価と詳細都市計画」野村総 合研究所 1991 年

24）田中啓一 「都市空間整備論 開発利益と財源負 担」有斐閣 1992 年 